\title{
THE PARTICIPATION OF THE ACADEMIC ARCHIVE IN THE SCIENTIFIC POLICY OF BAS IN THE LAST YEARS
}

\author{
Gabriela Vaptzarova, Darina llieva \\ dari_bas@abv.bg
}

Scientific Archive at the Bulgarian Academy of Sciences, Sofia, Bulgaria

\begin{abstract}
SA-BAS is a specialized unit and has its place and importance in the structure of the Academy: provides the Bulgarian scientific community with a complete resource base reflecting all aspects of society's development in different historical periods - one of the main tasks of any archive. The cultural heritage, preserved in SA$B A S$, fits well in the international priorities of European science and culture. Documentary sources provoke the development of research tasks in various fields: political and cultural history, art history, geography and cartography, geology, archeology, ethnology, etc. The obtained results are of great interest not only among the Bulgarian scientific community. This is the contribution of the Academic Archive to the cultural diversity of Europe and the world in historical and contemporary terms.
\end{abstract}

Keywords: Archive; BAS; History; Cultural and Historical Heritage

\section{УЧАСТИЕТО НА АКААЕМИЧНИЯ АРХИВ В НАУЧНАТА ПОАИТИКА НА БАН В ПОСАЕАНИТЕ ГОАИНИ}

\author{
Габриела Вапцарова, Аарина Илиева
}

Научен архив на Българска акалемия на науките, София, България

\begin{abstract}
Резюме: НА-БАН като специализирано звено има своето място и значение в структурата на Акацемията: обезпечава българската научна общност с пьлноценна изворова база, отразяваща всички страни на развитие на обществото в размични исторически периоди, което е еАна от основните заАачи на всеки архив. Културното наслеАство, съхранено в НА-БАН, Анес се вписва отлично среА межАународните приоритети на европейската наука и култура. Аокументалните извори провокират разработването на многобройни изслеАователски задачи в различни области: политическа и културна история, история на изкуството, географрия и картографрия, геология, археология, етнология и мр. Получените резултати предизвикват сериозен интерес не само среА българската научна колегия, но и в широк европейски контекст Увеличават възможностите за бъдещи интерАисциплинарни проучвания. Това е приносът на Акалемичния архив Към културното
\end{abstract}


разнообразие на Европа и света в исторически и съвременен план.

КАючови Ауми: архив; БАН; история; културНо историческо наслеАство

Българската акалемия на науките (БАН) възниква в бурната епоха на Възраждането, в годините на националното пробуждане, на осъзнаването и борбата в името на независимостта. Тя е уникален български френомен. Анес, от Аистанцията на времето, можем Аа кажем, че развитието на Акалемията е неразделна част от цялостния процес на формиране, изгражлане и развитие на българската Аьржава. БАН преминава през различни периоли, преживява Аоста сериозни преврати, но запазва своя пьрвоначален характер на духовно срелище и храм на българското просвещение.

Защо всяка голина отбелязваме Аатата на съзАаването на БАН? Аали се ръководим само от иАеята за юбилейна празничност по повоА на важни събития от нашата история? Аали целим Аа обогатим традицията на многобройните Аосегашни изслеАвания, част от които многостранно и твърде изчерпателно разискват темата? Поставените въпроси имат утвърАителен отговор с уговорката, че смисъльт на всяко честване е $\Delta$ а ни приближава $\Delta о$ актуалните проблеми на съвременността. През 2019 гоАина БАН чества 150 гоАини от своето създаване, а заелно с нея юбиляр е и Научният архив (НА) на БАН.

Започнал своята Аейност още с основаването на Българското книжовно Аружество (БКА) в Браила през септември 1869 г., НА може $а$ а се счита за най-старата архивна институция в страната. Профрилиран е като архив на документите на Акалемията (независимо от времето на тяхното съзАаване), а също и за личните фондове на български учени, членове на БАН.

В исторически аспект се формира значително по-рано от Аьржавните архиви и има собствен принос за опазването на Аокументалното културно-историческо наследство. Статутьт на Научния архив неелнократно през годините се променя. През 1947 г. Архивьт е обособен като организационна еАиница в Акалемията пол наименованието „Архивен отАеА”. Аве години по-КъСНо този отАеА е преобразуван в „Архивен институт при БАН”. САеАват още няколко 
структурни преобразувания като през определени периоли е бил самостоятелен, а през Аруги - „пол шапка".

От 1 януари 1994 г. с решение на ОС на БАН НА На БАН е обособен в самостоятелно специализирано звено на Акалемията и извършва слеАните Аейности: комплектува архивни Аокументи; извършва научно-техническа обработка и експертиза на тяхната ценност; организира използването им за научно-изследователски, справочни и Аруги цели; поАготвя Аокументални изАания и изложби; оказва метолическа помощ на полеленията на БАН в работата на техните Аеловодства и архиви. Цялата дейност на Научния архив е подчинена на важните стратегически залачи и приоритети на Акалемията. По-нататьшното развитие на НА се свързва както с традиционната му Ао този момент Аейност, така и с изгражАането му като съвременен изслеАователски центьр, базиран на знанието и като активен партньор в европейското научно-изследователско пространство.

НА-БАН като специализирано звено има своето място и значение в структурата на Акалемията: обезпечава българската научна общност с пьлноценна изворова база, отразяваща всички страни на развитие на обществото в различни исторически периоли, което е еАна от основните залачи на всеки архив. Културното наслеАство, съхранено в НА-БАН, АНес се вписва отАично среА межАународните приоритети на европейската наука и култура. Аокументалните извори провокират разработването на многобройни изследователски залачи в различни области: политическа и културна история, история на изкуството, географрия и картографрия, геология, археология, етнология и Ар.

Получените резултати предизвикват сериозен интерес не само среА българската научна колегия, но и в широк европейски контекст увеличават възможностите за бълещи интерАисциплинарни проучвания. Това е приносьт на Акалемичния архив към културното разнообразие на Европа и света в исторически и съвременен план. Независимо от сегашния Аинамичен периол на цялостна преориентация и стремеж към реорорми, необходимите промени трябва да се предприемат съобразно запазването на традициите, но и на новите обществени 
нагласи, за Аа прольлжи институцията $\Delta а$ изпьАнява своите фрункции в по^за на науката и обществото.

Приоритет за НА е текущото попьлване, подиьржане и разширяване на архивния фонн на БАН чрез комплектуване и обработка на Аокументалния масив. За 150 голини Акалемичният архив съхранява 548 архивни фонда. МежАу тях са: Аокументите на Акалемията от нейното създаване $А$ Анес, на братя Евлоги и Христо Георгиеви, Васил Арумев (митрополит КАимент), продр. Иван Шишманов, акалемик Спирилон Казанджиев, генерал Христофор Хесапчиев, проф. Боян Пенев, профр. Йорлан Иванов, профр. Васил Златарски, акалемик Георги Бончев, акалемик Тодор Павлов, на писатели като Иван Вазов, П. К. Яворов, П. Р. Славейков, Алеко Константинов и много Аруги. Разбирайки значението на архивната институция за опазване на научното наследство много съвременни

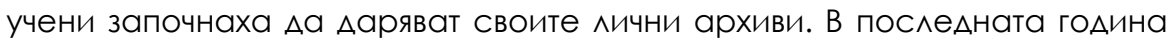
са комплектувани фондовете на акаА. Кири^ Боянов, акал. Михаил Станчев, акал. Петьр Аинеков, чл. кор. Румяна Ралкова, продр. Параскева Михай^ова, профр. Веска Николова, профр. Иван ТютюнАжиев и мр., което е безспорен принос за обогатяването на акалемичния Аокументален фонн.

В НА-БАН са регистрирани и 24 сбирки от архивни Аокументи, нотни материали, печати, мемоари и др. Има нал 100 частични постьпления на важни исторически Аокументи. В НА се съхраняват еАни от най-старите и ценни славянски и старобългарски ръкописи от IX $\Delta$ О XIX век, организирани в „Сбирка X”. МежАу тях са Битолският триод от XII век; Иван-Александровият песнивец от 1337 г.; псалтири и евангелия, сборници и Аамаскини, както и Ава ранни преписа на Паисиевата история.

ЕАна от основните и продьлжаващи орункции на Акалемичния архив е осъществяване на метолическо ръководство и контрол върху Аейността на институтските архиви и Аеловодните звена. Успех на НА е Изготвянето на осъвременени ИнАивиАуаАни номенкАатури за всички научни полеления, което гарантира еАинство в работата на цялата Акалемия. На тяхна база продьлжава полготовката на Аокументи на 
отАелните институти за постоянен прием. Перспектива и Аьлгосрочна стратегия на НА е работата по научно-изслеАователски проекти, в които участваме самостоятелно или като партньори. Особено внимание заслужава проектьт с Британската библиотека, насочен към опазване на културно-историческо наслелство в риск: „Застрашени фотоколекции за участието на прединАустриална България в три войни в началото на 20. век". Аруг голям проект на НА по Аиния на ЮНЕСКО е изготвянето и публикуването на енциклопедия „Жените в науката".

В межАународната Аейност на Акалемията НА участва със слеАните проекти: „Българо-полски научни и културни връзки през пьрвата половина на XX век въз основа на Аокументалните масиви, съхранявани в архива на БАН и ПАН", съвместно с Полската акалемия на науките (ПАН); „Русия и България. Неизвестни страници от историята на научните връзки по Аокументални източници в акаАемичните архиви на БАН и РАН", съвместно с Руската акалемия на науките (РАН); „Научни и културни връзки межлу румънската и българската интелигенция през XIX - XX век, съвместно с Румънската акалемия (РА). Подписани са договори и по нови теми с Архива на Чешката акалемия на науките (ЧАН) и Масариковия архив в Прага, както и с Националния архив на Беларуската акалемия на науките. Активно НА-БАН работи с българската диаспора в гр. Николаев, Украйна и Олеския Аьржавен архив, кълето е организирана съвместна международна конфреренция и е публикувано общо издание за пансиона на Тодор Минков по спомените на акалемик Петьр Абрашев.

Като межАуинститутски проекти могат $а$ a ce споменат: "Аигитален архив на Марин Аринов в НА фр. 104k", съвместно с Института по математика; "Изграждане на дигитализационен центьр за цифровизация на библиотечни и архивни Аокументи", съвместно с ЦБ БАН; „Руска Аиаспора в България 1878 - 2008 г.", с Централната библиотека на БАН. Предстои по-нататьшна активна работа по съвместни проекти със сроАни институции в Европа за Аообогатяването на акалемичния архив и неговото представяне преА обществеността. Като перспектива НА особено залага на съвместната работа със сродни регионални институции, а именно: окръжни Аьржавни архиви, 
музеи, театри, галерии и др., свързани с архивна, изследователска и популяризаторска Аейност.

През голините служителите на Научния архив концентрират усилията си към опазване и популяризиране на акалемичното Аокументално наслелство. На практика това става чрез десетки публикации на статии по страниците на специализираните изАания. Научни АоклаАи ежегодно продьлжават $А$ а се изнасят и на наши и межАународни научни фооруми - исторически конореренции, конгреси, симпозиуми, крьгли маси, четения и Ар. Основна залача в популяризаторската дейност на Акалемичния архив е създаването на високо художествени и съдьржателни изложби по конкретни поводи за представяне на българското културно наследство и постиженията на българската наука. Сътрудниците на архива са реализирали стотици изложби в Софрия, страната и чужбина, с което подАьржат ефрективно Аокументалното наслеАство и памет. ФонАовете на архива се използват и за създаването на Аокументални фоимми от пореАиците на Националната телевизия и за пьлнометражни филми. Почти не остава месец, в който уникални снимки и Аокументи да не привлекат вниманието на медиите и гражАаните.

В по-ново време сътрудници на Архива прольлжават тралицията Аа публикуват научни изслеАвания и Аокументални сборници: „Възстановяване на българо-американските Аипломатически отношения 1950 - 1960 г."; „120 голини българска статистика"; „Аневник" и „Походни писма на княз Н. ВА. ЯшвиА”(в 2 тома); „Източният въпрос" на Г. П. Генов (в 2 тома); "Аунавска България и Балканът", т. IV; монографоичен каталог „Съюз на южнославянските художници „Аала"; „Спирилон Казанджиев. Есета. Из архива"; "Аипломатическият Аневник на М. Сарафров"; „Енциклопедия Аарителството” (в 3 тома); „Архивното наслеАство на А^. Теодоров-Балан. Книжевни записи"; „Аончо Костов: най-виден генетик на XX век" и много Аруги важни за историята на българската наука и култура ИзАания.

През 2019 г. Научният архив започна нова пореАица по повоА 150 гоАишнината на БАН. Пьрвата книжка, вече изляз^а от печат, е посветена на най-Аьлгогодишният председател на БКА и БАН - Иван Евстратиев 
Гешов. ИзАанието е снаблено и с Ава Аиска Аигитализирани Аокументи от фоноовете на Акалемичния архив.

Основна залача прел НА е дигитализирането на научноизследователската инорраструктура и на най-ценните и поставени в риск Аокументи с историческа стойност и национално значение. ВъвежАането им в интернет ще осигури бърз Аостьп на заинтересованите лица Ао широката изворова база на НА.

Въпреки трудностите, които съпьтстват ежедневната работа на служителите, за своето Аьлголетно съществуване Научният архив израства и се утвьржлава като място за опазване и разпространение на инорормация за българската история, наука и култура. Обезпечаването на обществото с пьлноценна изворова база, отразяваща всички страни на неговото развитие във всеки конкретен исторически периол, е еАна от основните залачи на всеки архив. Ние не правим изключение.

\section{^итература / References}




\section{КУАТУРНО-ИСТОРИЧЕСКО НАСАЕАСТВО: \\ ОПАЗВАНЕ, ПРЕАСТАВЯНЕ, АИГИТААИЗАЦИЯ}

CULTURAL AND

HISTORICAL

HERITAGE

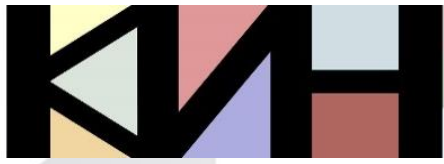

PRESERVATION PRESENTATION

DIGITIZATION
Материалите в сборника са обект на авторско право. Разрешава се безвъзмезАното ползване на техни електронни/ хартиени копия само за лична употреба или обучение, при пь^но цитиране на текущата страница и слеА писмена декларация от цитиращия за Аипса на търговски намерения. За копиране пол Аруга фрорма, препубликуване или публикуване на сървъри се изисква писмено разрешение и/или заплащане.

() Авторски колектив, 2019 Технически реАактори: Николай Ноев Калина Сотирова-Вълкова Ка^оян Николов

\section{Editors}

Galina Bogdanova

Vanya Mateeva

This work is subject to copyright. Open and free of charge use of digital/hard copies of publications is granted only for personal or educational use, with full citation of the current page, and after written declaration of the quoting side for not-commercial Intention. For any other reproducing types, republishing, photocopying, recording, or any other storage retrieval system/ server written permission and/or fee is required.

(C) Authors` Group, 2019

Technical editors:

Nikolay Noev

Kalina Sotirova-Valkova

Kaloyan Nikolov

Научна поредица: том 5, брой 2 (7)/2019

Science series: vol. 5 , issue $2(7) / 2019$

www.math.bas.bg/vt/kin

ISSN: 2367-8038 